\title{
Local monitoring of flowering and fruiting of Jernang, Daemonorops species in Sumatra, Indonesia
}

\author{
LARS SCHMIDT ${ }^{1, \vartheta}$, HIMMAH RUSTIAMI ${ }^{2}$, IDA THEILADE ${ }^{3}$ \\ ${ }^{1}$ Department of Geography and Natural Resource Management, University of Copenhagen. Rolighedsvej 23, 1958 Frederiksberg C, Denmark. Tel. +45 \\ 35331639. "email: 1sc@ign.ku.dk \\ ${ }^{2}$ Herbarium Bogoriense, Botany Division, Research Center for Biology, Indonesian Institute of Sciences. Cibinong Science Center (CSC), Jl. Raya \\ Jakarta - Bogor Km. 46, Cibinong, Bogor 16911, West Java, Indonesia \\ ${ }^{3}$ Department of Food and Resource Economy, Section for Global Environment. University of Copenhagen. Rolighedsvej 25, DK-1958 \\ Frederiksberg C, Denmark
}

Manuscript received: 4 September 2018. Revision accepted: 5 December 2018.

\begin{abstract}
Schmidt L, Rustiami H, Theilade I. 2019. Local monitoring of flowering and fruiting of Jernang, Daemonorops species in Sumatra, Indonesia. Biodiversitas 20: 118-125. Phenology and fruit production recordings of Jernang (Daemonorops spp.) were conducted in southern Sumatra over two one-year periods. Flowering and fruiting of 64 individual clumps with 570 stems $>2 \mathrm{~m}$ and 43 clumps with 478 stems $>2 \mathrm{~m}$ respectively were recorded on a monthly basis. Results showed that flowering and fruiting of Jernang took place throughout the year with a peak in April and May and at low level in September to March. Duration of male inflorescences was 23 months. Fruits were usually harvested for resin 2-3 months after flowering. Sex ratio of clusters was about 1:1. Flowers and fruits were produced on vigorously growing stems that had reached canopy light exposure. Clusters consisted of from 2 to 36 stems. In some clusters, all stems bore reproductive organs; in others, only few stems had flowers or fruits. Female clusters had significantly more stems than male clusters, but male clusters produced more inflorescences than did females. About $80 \%$ of the clusters during the first year's survey and 50\% the second year produced flowers. The most vigorous male clusters produced more than 80 inflorescences with up to 15 on a single stem within a year. The highest producing female clusters produced 12 inflorescences in a year with up to five inflorescences and four infructescences per stem in a year. The data was primarily collected by trained local monitors. They knew the species well and were used to spot flowers and fruits. However, since the local monitors were also all Jernang collectors, they usually picked fruits before maturity, and the full development into mature fruits was thus interrupted.
\end{abstract}

Keywords: Dragonblood, Jernang, local monitoring, NTFP, phenology, production potential, seasonality

\section{INTRODUCTION}

Increased commercial interests coupled with the depletion of the natural resource base in Sumatran forests have strengthened the interest for cultivating traditionally collected NTFPs (Yetti et al. 2013). Sumatran Dragonblood refers to a small group of species from the genus Daemonorops, belonging to the group of climbing palms, in SE Asia known as rattans (Dransfield 1979; Dransfield and Manokaran 1993; Sunderland and Dransfield 2002; Rustiami et al. 2004). Rattans are primarily collected and grown for their flexible stems, which are processed into furniture, baskets and other strong woven utilities (Johnson 1998; Sunderland and Dransfield 2002). Some Daemonorops species produce a sticky-hard resin cover of each developing fruit. The resin is traded to e.g. Singapore, where it is used in cosmetic and traditional medicine (Sulasmi et al. 2012a and b; Yetti 2013; Jura-Morawiec and Tulik 2016). The genus Daemonorops contains more than 100 species (Dransfield 1979; Dransfield and Manokaran 1993; Rustiami et al. 2004). Resin yielding Daemonorops species, which in Malay languages are known as 'Jernang', only include 10 species of which Daemonorops draco is the most common harvested species (Rustiami et al. 2004). We apply the Malay word Jernang when referring to resin producing rattans, avoiding the English term Dragonblood because the latter may refer to a number of other resin and sap producing species from different plant families (Pearson and Pendergast 2001; Gupta et al. 2008).

Jernang species are confined to Borneo and Sumatra and stretching into West Java (Dransfield et al. 2002). As other rattans, Jernang grow in the rain forest, where the seeds germinate under shaded conditions. Stems grow straight upwards from the cluster, but if there is no support tree nearby, they bend over and continue to grow horizontally until they encounter a support tree. Once that happens, the stem will climb upwards using stem thorns and cirrus to attach itself to the tree (Sunderland and Dransfield 2002; Isnard and Rowe 2008). Flowering starts when the stem has reached light exposure in the crown. If the support tree falls, the stems usually continue to grow using a new support tree. New stems grow continuously from the root, which form a clump or cluster (Sunderland and Dransfield 2002), in Malay languages referred to as 'rumpun'. Old clusters consist of many individual stems. Adding new stems and increasing the length increase the chance for reaching the canopy and thus produce flowers and fruits.

The species are dioecious (Dransfield 1979; Rustiami et al. 2004) and the sex of the plants can only be identified 
from reproductive structures (flowers and fruits). During the initial stage, male and female inflorescences look much alike as the inflorescences are enclosed in bracts (Dransfield 1979; Rustiami et al. 2004). Only inspection of individual flowers can tell whether the male or female part has developed. Close examination of individual inflorescences is difficult in practice because the flowering is in the canopy. When the inflorescences open, males may be identified by the presence of white anthers and females by initial fruit formation.

According to Rustiami et al. (2004) and Sulasmi et al. (2012b) at least two high producing Jernang species exist in the monitoring area in Jambi Province viz. Daemonorops draco (Willd.) Blume and Daemonorops didymophylla Becc. Local farmers know the species by the names Kalamuay, Umbut, Rambai, and Puyuh. The translation of local names may be ambiguous. Sulasmi et al. (2012b) identified the local name Kelemunting in Jebak Village (close to Lamban Sigatal) as D. didymophylla and we believe it is the same as Kalamuay in Lamban Sigital. The three other names, Umbut, Rampai and Puyuh, which collectors distinguish by size and firmness of fruit attachment to the infructescence, probably all refer to $D$. draco.

\section{Phenology studies}

Reproductive phenology in aseasonal, wet tropics often shows little seasonal variation; several species flower throughout the year, albeit usually with peaks during specific periods (Janzen 1978, Hilty 1980, Corlett 1990). Flower initiation is often triggered by light $(\mathrm{Ng} \mathrm{1977}$; Borchert 1983). Duration of development from flowering to fruit maturity varies from species to species, - in tropical lowland from few months to up to a year. Several late successional species flowers immediately after seed dispersal (Singh and Kushwaha 2006). Despite the economic interest in Jernang, little is known about their phenology and fruit production. Sulasmi et al. (2012a and b) and Yetti (2013) estimated production from individual cultivated plants based on local information from interviews. Long-term observations of the reproductive biology in its natural environment are lacking, and the present survey is the first published phenology study where individual plants of Jernang have been observed and recorded over a prolonged period.

Phenology observations should at least be undertaken for one full year to follow the annual cycle. For species growing far from research centres and botanical institutions, lengthy recording is best undertaken by local residents. Local monitoring for ecological surveys has been used in connection with biodiversity surveys in temperate areas, e.g. birds (Sharrock 1976) but is a relatively new concept in tropical research (Danielsen et al. 2005; Janzen 2004; Zhao et al. 2016). However, it is often the only available method to record information from remote areas. In addition to data collection itself, using local monitors provides an opportunity to train, share ownership to data, and strengthen the communication between researchers and local people (Janzen 2004). The latter was relevant since this study was carried out as a support activity to the protection of Harapan Rain Forest (https://harapanrainforest.weebly.com/)

The objectives of the study was to; (i) document flowering and fruiting seasonality and quantity from individual plants of Jernang in order to estimate production potential; (ii) explore if clusters with many and longer stems produced more inflorescences and whether there was a difference between male and female clusters in reproductive behaviour, and (iii) evaluate the efficiency and reliability of local villagers recording phenology of individual plants over an extended period of time.

\section{MATERIALS AND METHODS}

The field study was done in and around village Lamban Sigatal (2'11'10.38',S, 102 $\left.{ }^{\circ} 57^{\prime} 59.70^{\prime \prime} \mathrm{E}\right)$ at the border between Jambi and South Sumatra provinces, Indonesia. The area is humid tropical with annual rainfall about 2300 $\mathrm{mm}$, with a seasonal drop during the months May to October (Figure 1). The natural vegetation is moist rain forest (Laumonier 1997; Harrison and Swinfield 2015) albeit much of the area has been logged and transformed into agriculture, or plantations of oil palms, rubber or Acacia mangium.

The studies took place over two separate one-year periods. The first period from September 2013 to August 2014 included records of 64 clusters and 769 stems. The sampled clusters were located in two separate community rubber plantations established by the village in collaboration with a local NGO, KITA Buana in 2005-2006 (http://gitabuanaforum.blogspot.dk/), and scattered plants in and around the village. According to local information the Jernang was planted 2-3 years after planting the rubber meaning that the clumps were 5-6 years old at the time of monitoring. The second survey was done from April 2016 to March 2017 and included 43 clusters with a total of 736 stems. All clusters grew on one private farm, in a 2 hectare rubber plantation and a home garden close to the house. Jernang had been planted continuously under the mature rubber trees for about 15 years and the stand thus contained both old and new plants.

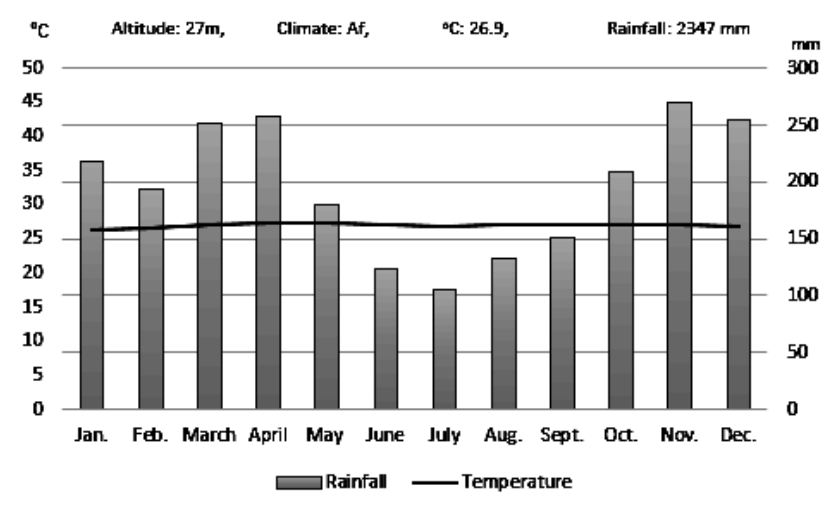

Figure 1. Climate diagrams, Jambi, Southern Sumatra: https://en.climate-data.org/region/1210/ 
The majority of the labelled individuals were named by locals as Rambai and Kalamuai. These were identified to D. draco and D. didymophylla. However, since several individuals in the sample were identified to genus level only because of lack of fertile material, the sample was treated as one species group of Jernang, notwithstanding it consisted of at least two different Daemonorops species.

During the two monitoring periods, the authors visited the sites and provided on-the-job training for the local monitors. During the training, the authors and local monitors labelled all clusters and recorded GPS position, number and length of stems, support tree species, and information about the growth site. We used a 1.5 meter long stick for measuring the length of short stems, and measuring tape for measuring longer horizontal growth. The length of vertical growth into the canopy was estimated. Since no inflorescences were encountered on shorter stems, it was decided to only record on stems longer than 2 meters at the time of start of monitoring. Each stem longer than 2 meters was tagged with a number stamped into a small metal plate and a red plastic label to make it easier to find the tags. The number of individually recorded stems $>2$ meter was 570 stems in the first survey and 478 in the second survey.

The authors and monitors did the first recording of all plants together as part of the training. The first monitoring team was a group of three teenagers, who were all familiar with the species of Jernang and two of them were active in Jernang collection. The latter was important for both their motivation and their experience in spotting inflorescences. A farm owner assisted by his adult daughter conducted the second monitoring. The farmer was one of the most experienced Jernang growers in the village. Informal discussion with monitors during the training sessions provided additional information from their observations of the species.

Monitors were provided with binoculars for the surveys, forms for monthly registration of flowering and fruiting of each cluster with breakdown on individually tagged stems, and a general guideline for filling in the forms, all in Bahasa Indonesia. In addition, they received an incentive per three months' submission of data.

The monthly monitoring included recording the number of inflorescences and, for females, infructescences of each stem. Inflorescences were recorded if they had a distinct brown bract. For males recording stopped when the inflorescence had disintegrated. For females, visible fruitlets defined the end of flowering and start of infructescence. The data forms from the first survey were submitted to the headquarters of Harapan Rain Forest where it was keyed in and forwarded to the coordinator in Denmark. During the second survey, data was submitted electronically by the local monitor directly from the village to the coordinator. The analysis was done using simple Excel tools, sums, average, and chi-square-test analysis on sex ratio.

Number of inflorescences and infructescences produced during the year was estimated based on monthly records, since individual inflorescences could not be tagged. Males were estimated based on the observations that inflorescences are usually dehisced after 2-3 months. Female inflorescences were the sum of new appearing inflorescences through the year, where previous inflorescences were shed or counted as fruits. Infructescences were counted as newly appearing infructescences over the year. Potential fruit production was estimated by counting individual fruits of 6 infructescences and weighing 10 individual fruits using a portable digit scale.

Some errors were encountered in the filled forms. For example, omission of inflorescence records on some stems recorded previous and subsequent months, and a few errors of male inflorescences that turned out to develop fruits. However, all errors were, to the best of our knowledge, rectified from the whole data set, or for the 2013-14 monitoring, clarified during a follow-up visit in 2016.

\section{RESULTS AND DISCUSSION}

Each cluster in this survey had from 6 to 35 stems (average 18), of which 2-30 (average 12) were more than 2 meters long. A summary of the results for the two years is shown in table 1 . The sex ratio of the 51 flower producing clusters during the 2013-2014 survey was 26 males: 25 females; in 2016-2017 the ratio was 9 males: 12 females of 21 flowering clusters. Neither of those differed significantly $(\mathrm{P}<0.05)$ from a $1: 1$ sex ratio. About $20 \%$ of the first survey year clusters and $50 \%$ of the second year did not produce any flowers or fruits.

Most theoretical predictions on the inert sex ratio in dioecious species support the 1:1 ratio (Bawa 1980, Dellaporta and Calderon-Urrea 1993, Tanurdzic and Banks 2004). The 1:1 ratio was also found in related dioecious Calamus palustris Griff. In Malaysia (Choong et al. 2009) and $C$. castaneus Griff. in Thailand (Aroonrat and McKey 2012).

Inflorescences were often produced by few stems only, even when the cluster consisted of more than 30 individual stems. There were also examples of clusters with few (3-5) stems that all flowered. These observations suggest that the individual stems largely behave as individual plants, like branches on a tree, where only those exposed to light reproduce. Table 2 shows an extremely productive male flowering cluster (B11) bearing 86 inflorescences, which was almost the total number of male inflorescences in the stand. 51 of these were borne on 4 stems, and those 4 stems were also the most productive during the two years' recording. None of the female clusters produced more than 12 inflorescences and 9 infructescences. Individual female stems produced not more than 2-4 infructescences in a year. The sex ratio of reproductive stems showed a small and insignificant female bias ( 80 males: 90 females) during the first survey, but a high male bias during the second survey (20 males: 8 females). In the first survey the female bias increased in stems longer than 2 meters. It may be an effect of farmers' cutting some male stems when they realize that they will not produce fruits (Marcelle 1995; Vasudeva et al. 2016). However, farmers rarely remove entire male clusters as they are aware of the importance of 
males for fruit production. Anthropogenic interference could also cause male bias. In some dioecious species, females are cut down for fruit collection (Sheil and Wunder 2002). According to collector's information it is considered 'bad manners' and hence not normal practice for Jernang, even in open access forest, but it is also mentioned that it happens. Anthropogenic impact on the sex ratio is thus more likely on individual stems than on cluster level.

Dioecious plants tend to produce much more male than female flowers (Bawa 1980), and the phenomenon was apparent in the total number of inflorescences in Jernang. The sex ratio was strongly male biased in both surveys with 176 males: 148 females in the first survey and 90 males: 8 females in the second. On average about 50\% (80/158) male stems over 2 meters and about 30\% (90/303) female stems over 2 meters produced flowers during the first survey. The figure covers a large variation from one male cluster consisting of 5 stems over 2 meters long that all produced flowers, to several others where only 1 or a few stems of more than 30 produced flowers. Some of the most productive stems are listed in Table 2.

Fruiting record (Table 1) shows the number of immature developing infructescences, i.e. anything between 2 and 12 months after anthesis. In most cases, fruits were harvested after 2-3 months for resin extraction. We do not know whether continuous early harvest could lead females to produce new inflorescences. Fruit weight of 10 individual fruits at near-mature size ranged from 2.0-3.4 $\mathrm{g}$ and each infructescences contained about 75-100 individual fruits. Hence, the weight of fruits from an infructescence is 150-340 grams. The most productive single cluster in our survey (A24) produced 9 infructescences in a year equivalent to $1.3-3.1 \mathrm{~kg}$ fruits. This is significantly less than the $10-60 \mathrm{~kg}$ fruits per cluster per year reported by Sulasmi et al. (2012a). In our survey, the most clusters produced far less fruits and there was a big variation from plant to plant. Using our base figures of weight of fruits per infructescence (150-340), $60 \mathrm{~kg}$ fruits is equivalent to $175-400$ infructescences per cluster.

Flowering stems produce inflorescences continuously. Several of the flowering stems labelled in 2013 were still growing when we re-visited the area in 2016. That indicates an iteroparous (pleonanthic) habit in which the plant has several reproductive events during their lifetime (Sunderland and Dransfield 2002, Dransfield and Manokaran 1993).

Flowering male stems were on average longer than nonflowering stems. In females, there was no difference. The shortest stem where male inflorescences were produced was $2.5 \mathrm{~m}$ and the shortest female $3 \mathrm{~m}$ (Table 3 ).

The phenology record showed that flowers and fruits were produced and present throughout the year, but also showed a certain seasonality (Figure 2). April-June flowering was most pronounced for male flowering. Comparison of phenology with records of rainfall (Figure 1) shows that main flowering occur during the dry months May to August, albeit male flowering starts already in the wet month of April. The period from April to July was also the period with reportedly highest number of infructescences. However, the number of infructescences declines from the month of August. That is the beginning of the most intensive harvest according to Sulasmi et al. (2012b), but where their reported season lasted into December, most fruits were apparently already harvested during August, probably because the monitors had already identified them by the months of August and chose to pick them. Flowering and fruiting was very poor in the second survey with only 9 flowering males and 12 flowering or fruiting females (data not shown).

Table 1. Reproductive manifestation of males and females. Most of the clusters of the 2013-14 (A) monitoring were planted about 8 years before monitoring. Clusters of the 2016-17 (B) monitoring were different age, from 2-8 years.

\begin{tabular}{|c|c|c|c|c|c|c|}
\hline Sex & $\begin{array}{c}\text { Number } \\
\text { of } \\
\text { clusters } \\
\end{array}$ & $\begin{array}{c}\text { Total } \\
\text { number of } \\
\text { stems } \\
\end{array}$ & $\begin{array}{c}\text { Number } \\
\text { of stems } \\
>2 \mathrm{~m} \\
\end{array}$ & $\begin{array}{c}\text { Number of } \\
\text { flowering or } \\
\text { fruiting stems }\end{array}$ & $\begin{array}{l}\text { Total number } \\
\text { of } \\
\text { inflorescences }\end{array}$ & $\begin{array}{c}\text { Total number } \\
\text { of } \\
\text { infructescences }\end{array}$ \\
\hline \multicolumn{7}{|l|}{ Monitoring 2013-2014 } \\
\hline Male & 26 & 328 & 158 & 80 & 176 & \\
\hline Female & 25 & 441 & 303 & 90 & 148 & 72 \\
\hline Unknown & 13 & 147 & 109 & 0 & 0 & \\
\hline Total & 64 & 769 & 570 & 170 & 324 & 72 \\
\hline $\mathrm{P}$, deviation from sex ratio $1: 1$ & 0.89 & $4,6 \times 10^{-5}$ & $1,5 \times 10^{-11}$ & 0.44 & 0.12 & \\
\hline \multicolumn{7}{|l|}{ Monitoring 2016-2017 } \\
\hline Male & 9 & 154 & 105 & 20 & 90 & \\
\hline Female & 12 & 258 & 172 & 8 & 8 & 8 \\
\hline Unknown & 22 & 324 & 201 & 0 & 0 & \\
\hline Total & 43 & 736 & 478 & 28 & 98 & 8 \\
\hline $\mathrm{P}$, deviation from sex ratio $1: 1$ & 0.51 & $3.0 \times 10^{-7}$ & $5,7 \times 10^{-5}$ & 0.02 & $1.2 \times 10^{-16}$ & \\
\hline
\end{tabular}


Table 2. The 10 most reproductive clusters and individual stems of each sex during the 1-year recording period. A-clusters refer to year 2013-14, B-clusters refer to 2016-17

\begin{tabular}{|c|c|c|c|c|c|c|c|c|c|c|c|}
\hline \multicolumn{5}{|c|}{ Male } & \multicolumn{7}{|c|}{ Female } \\
\hline 离 & 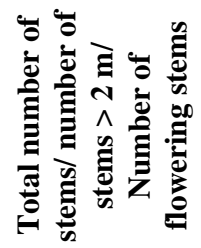 & 휼 & 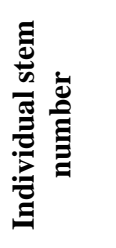 & 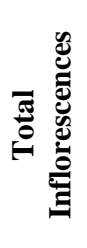 & 矛 & 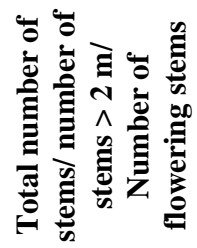 & 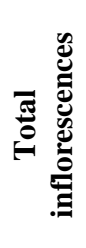 & 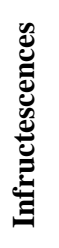 & 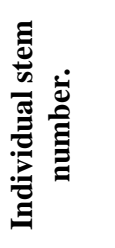 & 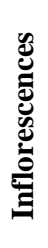 & స \\
\hline B11 & $15 / 12 / 10$ & 86 & B11.1 & 15 & $\mathrm{~A} 02$ & $9 / 4 / 4$ & 12 & 4 & A35.18 & 5 & 4 \\
\hline A 32 & $36 / 17 / 10$ & 21 & B11.9 & 13 & A57 & $7 / 7 / 5$ & 11 & 8 & A02.1 & 4 & 3 \\
\hline A33 & $36 / 17 / 5$ & 21 & B11.4 & 11 & A44 & $11 / 9 / 6$ & 9 & 6 & A 37.4 & 4 & 3 \\
\hline B21 & $15 / 7 / 4$ & 17 & B11.10 & 12 & A37 & $33 / 25 / 6$ & 9 & 2 & A44.5 & 3 & 3 \\
\hline A38 & $17 / 4 / 3$ & 17 & A33.1 & 8 & A50 & $12 / 6 / 4$ & 8 & 3 & A2.3 & 4 & 2 \\
\hline A47 & $17 / 8 / 5$ & 14 & A 33.3 & 7 & A24 & $17 / 6 / 3$ & 7 & 9 & A40.11 & 3 & 4 \\
\hline A22 & $16 / 10 / 6$ & 14 & A 33.4 & 7 & A58 & $27 / 6 / 5$ & 7 & 7 & A24.11 & 3 & 3 \\
\hline A 23 & $14 / 14 / 5$ & 11 & A22.1 & 7 & A3 & $6 / 5 / 5$ & 6 & 2 & A24.15 & 2 & 3 \\
\hline A36 & $16 / 7 / 4$ & 10 & A38.1 & 6 & A52 & $13 / 11 / 6$ & 5 & 4 & A28.3 & 2 & 2 \\
\hline
\end{tabular}

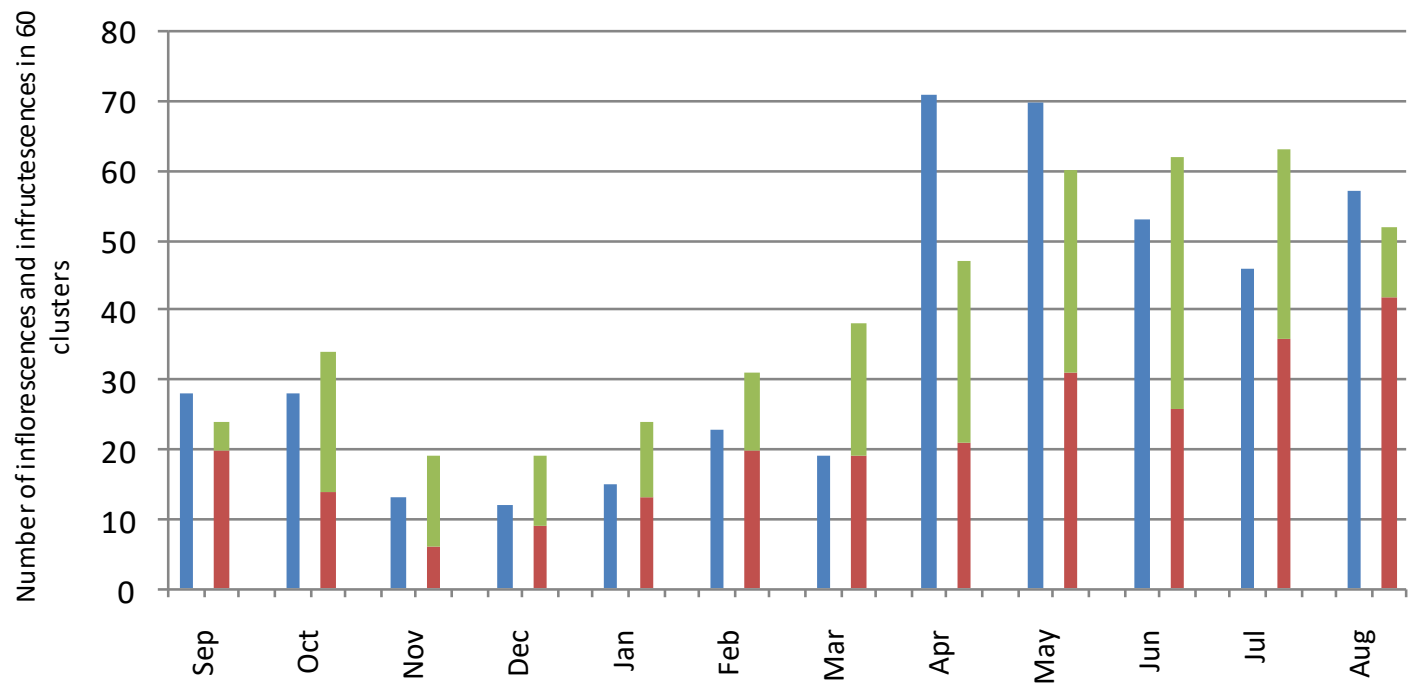

Male inflorescences $\square$ Female inflorescences Infructescences

Figure 2. Flowering and fruiting records during the year from September 2013 to August 2014

Table 3. Average length of non-flowering and flowering / fruiting stems of males and female clusters during the 2013-14 survey

\begin{tabular}{llcc}
\hline & & \multicolumn{2}{c}{ Length, meters } \\
\cline { 3 - 4 } & & Average & Range \\
\hline \multirow{5}{*}{ Males } & Non-flowering stems & 4.2 & $2-10$ \\
& Flowering stems & 7.3 & $2.5-17$ \\
& Non-flowering stems & 6.9 & $2.5-20$ \\
& Flowering / fruiting & 6.9 & $3-16$ \\
& stems & & \\
\hline
\end{tabular}

Records of single-inflorescence stems showed that male inflorescences disintegrated and shed after 2-3 month. Female inflorescences develop into infructescences and there is no clear line between the two stages. Most singleinflorescence stems showed that female inflorescences lasted for 2-3 months and then were recorded as infructescences. The inaccuracy due to the lack of individual labelling of inflorescences was small, because there were only few female inflorescences on each stem. Most infructescences were recorded 2-4 months. According to the Jernang farmer monitoring in 2016-17, the duration 
from the inflorescence appear to full maturity takes a full year. His observations were based on infructescences deliberately left unharvested in order to use the seed for propagation.

The correlation between stem length and flowering was ambiguous (Table 3). For males, there was a clear tendency that primarily longer stems flowered. That was not clear in females. Both sexes had short (2.5-3 meter long) flowering stems and long (>15 meters) without flowers. Increased stem length increased the chance of reaching the canopy, but at relatively open sites, adequate sunlight to trigger flowering was available at lower height. Some of the long stems had several meters of horizontal growth. However, compared to natural forests, the length of the flowering stems in the rubber plantations were shorter because the Jernang was planted close to a support tree.

We found more male than female inflorescences when measured per cluster, although the females had more stems $>2$ meters than males (Table 1). There was a strong correlation between number of stems per cluster and number of inflorescences for males $\left(\mathrm{R}^{2}=0.777\right.$, Figure $\left.3 \mathrm{~A}\right)$ while such relation was almost absent for females $\left(\mathrm{R}^{2}=0.029\right.$, Figure $\left.3 \mathrm{~B}\right)$. We presume that it is because flowering in females was generally sparser.

The number of inflorescences and infructescences was low in the last year of recording. Although both number of, and length of stems were comparable to the first survey, the average number of inflorescences and infructescences produced was much lower. Light was presumably the limiting factor since many of the plants were planted between fully grown rubber trees, while the plants planted in the community plantations of the first survey were planted while the rubber trees were small. However, periodicity could also be a factor. In SE Asia, episodes of mass or general flowering occur at irregular intervals, and are linked to events of prolonged drought ( $\mathrm{Ng} \mathrm{1977,} \mathrm{Appanah}$ 1993, Sakai et al. 2006). We do not know if Jernang show enhanced flowering in connection with general flowering episodes, but such dependency should be documented by prolonged phenology studies of several years.

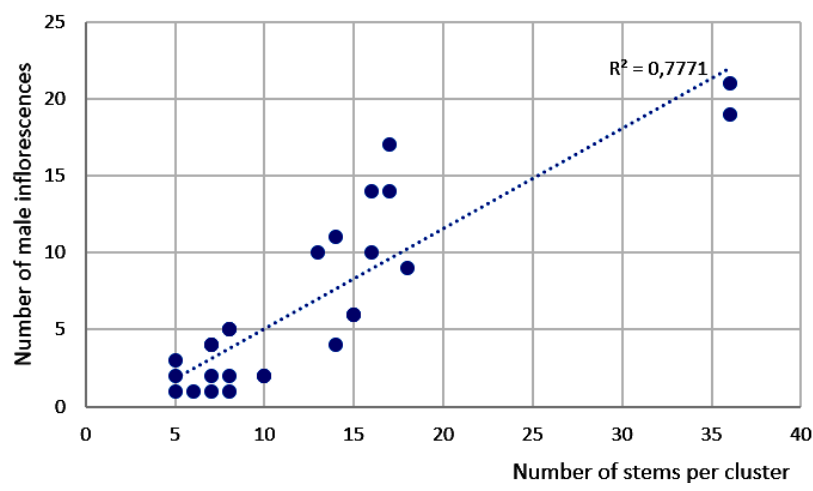

$\mathbf{A}$
Evaluation of the local monitoring could be summarized in following points: (i) The monitors knew the species well and were very good in spotting flowers and fruits even in dense canopies. (ii) Recording was done timely. For the 2013-14 data set, we found few errors mainly missed recordings of individual inflorescences, or mistakes in the identification of male and female inflorescences. We found no errors in the 2016-2017 records and the manual appeared to have been meticulously followed. (iii) The first team of monitors used the monthly survey to locate and harvest infructescences. The second team, the private farmer and his daughter, claimed that tagging stems and leaving infructescences for observation caused intrusion and theft of the fruits. (iv) The quarterly collection of monitoring forms and cash payment was cumbersome and added travel costs to the monitoring. Data entry and transfer of Excel files by the monitors in the second survey made the monitoring more cost-efficient. Likewise, mobile pay made payment efficient. (v) Initial collaborative work such as tagging stems, measuring stem length and recording supplementary information in connection with training motivated the monitoring teams to be efficient and reliable during data collection. (vi) Working hands on with the local monitors generated substantial additional information about the habit and phenology of Jernang.

Local monitoring is a practical approach to do lengthy recording on flowering and fruiting of Jernang. With the drawback of occasional missing data, fading off enthusiasm with time, skipping some cumbersome tasks like quarterly measurement of stems, and occasional errors filling in the records, the method generated a lot of information on Jernang, that could not have been done without local monitors. Except from the missing data on individual stem development, and individual inflorescence development, which was disqualified part of the study, other errors could be rectified during data cleaning and consultation. Improved communication to remote areas allows local monitoring to be used in new connections. Conflicting interests was a major limitation. Most people in the village collected Jernang. There was competition on

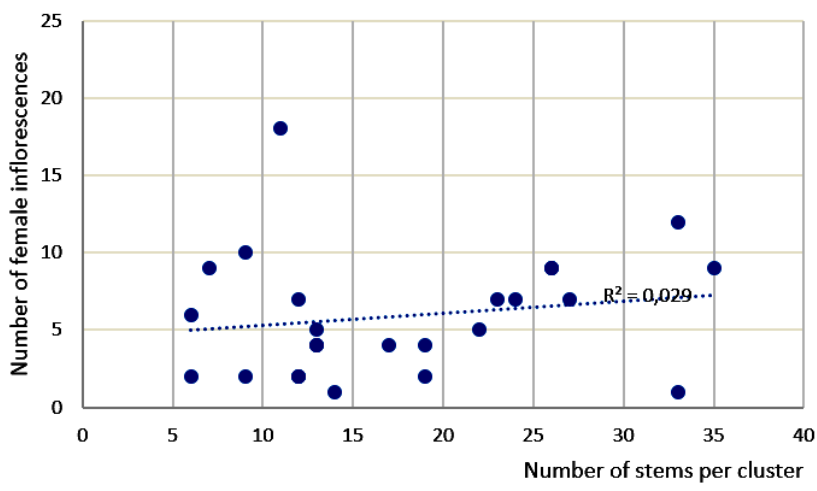

Figure 3. Correlation between number of stems and number of inflorescences. A. In male clusters, B. Female clusters 
accessing the infructescences, which were usually fetched at the most 2-3 months after the first observation. Jernang has traditionally been considered a wild fruit and is regarded as free for collection (Sulasmi et al. 2012a and b, Yetti 2013). Although all the monitored Jernang clusters grew on private land, theft of fruits was common. According It was thus in practice not possible to follow fruit development up to maturity

\section{Conclusion and recommendations}

A Jernang cluster consists of up to 40 stems usually with a few vigorously growing, flowering and, for females, fruiting stems. Development from flower to mature fruits is about a year, but most fruits are harvested after 2-3 months. Flowering and fruiting occur throughout the year but with peak flowering from April to August. Individual clusters may produce up to 9 female infructescences per year, most of which are produced by a few vigorously growing and light-exposed stems. Male plants can potentially flower profusely with almost a hundred inflorescences per year. The sex ratio of planted Jernang clusters was found to be $1: 1$. The local monitoring system used in this survey proved efficient in timely observations and recordings. However, thorough training on methods and reporting is essential and frequent feedback necessary to keep the enthusiasm. Jernang has taken its first steps from wild collection into cultivation. That makes long-term studies, which can provide more detailed information on phenology and fruiting and their fluctuations from year to year, easier. More long-term studies are also needed to assess the fate of individual stems and how management like light exposure and harvest may influence reproduction.

\section{ACKNOWLEDGEMENTS}

The authors wish to thank Danida, Danish Development Assistance for financial support for fieldwork through their support to Harapan Rain Forest Project. We are thankful to the village authorities in Lamban Sigatal for approving the research, to the Research Centre of Harapan Rain Forest Project for collecting and submitting the data of the first survey, and to the monitoring teams for their field work as well as sharing their experience of Jernang.

\section{REFERENCES}

Appanah S. 1993. Mass flowering of dipterocarp forests in the aseasonal tropics. J Biosci 18 (4): 457-474

Aroonrat MK, McKey D. 2012. Flowering phenology and mimicry of the rattan Calamus castaneus (Arecaceae) in southern Thailand. Botany 90: 856-865.

Bawa KS 1980. Evolution of dioecy in flowering plants. Ann Rev Ecol Syst 11: 15-39.

Borchert R. 1983. Phenology and Control of Flowering in Tropical Trees. Biotropica 15 (2): 81-89.

Choong CY, Wickneswari R, Fatimah S. 2009. Survival and sex ratio of a planted rattan Calamus palustris Griff. Populatiuon: Implication to seed production and management. J Biol Sci 9 (6): 633-636.

Corlett RT. 1990. Flora and reproductive phenology of the rain forest at Bukit Timah, Singapore. J Trop Ecol 6 (1): 55-63.
Danielsen F, Burgess ND, Balmford A. 2005. Monitoring matters: examining the potential of locally-based approaches. Biodivers Conserv 14:2507-2542.

Dellaporta SL, Calderon-Urrea A. 1993. Sex determination in flowering plants. Plat Cell 5: 1241-1251.

Dransfield J. 1979. A manual of the rattans of the Malay Peninsula. Malayan forest records 29, Forest Department, Ministry of Primary Industries, West Malaysia.

Dransfield J, Manokaran N. 1993. Plant resources of South-East Asia (PROSEA), No 6. Rattans. Pudoc Scientific Publishers, Wageningen.

Dransfield J, Tesoro FO, Manokaran N. 2002. Rattan - Current Research Issues and Prospects for Conservation and Sustainable Development. Non-Wood Forest Products No. 14. FAO, Rome.

Gupta D, Bleakly B, Gupta RD. 2008. Dragon's blood: botany, chemistry and therapeutic uses. J Ethnopharmacol 115: 361-380.

Harrison R, Swinfield T. 2015. Restoration of logged humid tropical forests: An experimental programme at Harapan Rainforest, Indonesia. Trop Conserv Sci 8 (1): 4-16.

Hilty SL. 1980. Flowering and Fruiting Periodicity in a Premontane Rain Forest in Pacific Colombia. Biotropica 12 (4): 292-306.

Isnard S, Rowe NP. 2008. The climbing habit in palms: Biomechanics of the cirrus and flagellum. Am J Bot 95 (12): 1538-1547.

Janzen DH. 1978. Seeding pattern in tropical trees. In: Tomlinson BP, Zimmerman MH. (eds): Tropical Trees as Living Systems. Cambridge University Press, Cambridge, UK.

Janzen DH. 2004. Seeting up tropical biodiversity for conservation through non-damaging use: participation by parataxonomists. J Appl Ecol 41: 181-187.

Johnson DV. 1998. Tropical Palms. Non-Wood Forest Products 10. FAO Regional Office for Asia and the Pacific. Food and Agriculture Organisation of the United Nations, Rome.

Jura-Morawiec J, Tulik M. 2016. Dragon's blood secretion and its ecological significance. Chemoecology 26: 101-105.

Laumonier Y. 1997. The Vegetation and Physoigraphy of Sumatra. Geobotany 22. Kluwer Academic Publishers, The Hague.

Marcelle GB. 1995. Production, Handling and Processing of Nutmeg and Mace and Their Culinary Uses. Food and Agriculture Organisation of the United Nations, Rome.

Ng FSP. 1977. Gregarious flowering of dipterocarps in Kepong (1976). Malays For 40: 126-136.

Pearson J, Prendergast HDV. 2001. Collection corner. Daemonorops, Dracaena and other Dragon's blood. Econ Bot 55 (4): 474-477.

Rustiami H, Setyowati FM, Kartawinata K. 2004: Taxonomy and uses of Daemonorops draco. J Trop Ethnobiol I (2): 65-75.

Sakai, S, Harrison RD, Momose K, Kuraji K, Nagamasu H, Nakashizuka T. 2006. Irregular droughts trigger mass flowering in aseasonal tropical forests in Asia. Am J Bot 93 (8): 1134-1139

Sharrock JTR. 1976. The Atlas of Breeding Birds in Britain and Ireland. T. \& AD. Poyser Ltd. London.

Sheil D, Wunder S. 2002. The value of tropical forest to local communities: complications, caveats, and cautions. Conservation Ecology 6 (2): 9. http://www.consecol.org/vol6/iss2/art9.

Singh KP, Kushwaha CP. 2006. Diversity of flowering and fruiting phenolohy of trees in a tropical deciduous forest in India. Ann Bot 97: 265-276.

Sulasmi IS, Nisyawati, Purwanto Y, Fatimah S. 2012a. Jernang rattan (Daemonorops draco) management by Anak Dalam Tribe in Jebak Village, Batanghari, Jambi Province. Biodiversitas 13 (3): 151-160.

Sulasmi IS, Nisyawati, Purwanto Y, Fatimah S. 2012b. The population of Jernang rattan (Daemonorops draco) in Jebak Village, Batanghari District, Jambi Province, Indonesia. Biodiversitas 13 (4): 205-213.

Sunderland TCH, Dransfield J. 2002. Species profiles rattans: (Palmae: Calamoideae). In: Dransfield J, Florentino TO, Manokaran N. (eds.). Rattan, Current Research Issues and Prospects and Sustainable Development. Non-Wood-Forest-Products. Food and Agriculture Organisation of the United Nations, Rome.

Tanurdzic M, Banks JA. 2004. Sex-determining mechanisms in land plants. Plant Cell 16: 61-71.

Yetti, Hariyadi B, Murni P. 2013. Studi etnobotani jernang (Daemonorops spp.) pada masyarakat desa Lamban Sigatal dan Sepintun kacamatan pauh kabupaten Sarolangun Jambi [Ethnobotany of Jernang (Daemonorops spp.) in the community of Lamban Sigatal and Sepintun, Puah, Sarlongun, Jambi]. Biospecies 6 (1): 38-44. [Indonesian] 
Vasudeva R, Reddy RBMC, Sthapit B. 2016. A suite of propagation and management in the Central Western Ghat region of Karnataka, India In: Sthapit B, Lamers HAH, Ramanatha VR, Arwen Bailey A. (eds.): Tropical Fruit Tree Diversity: Good Practices for in Situ and On-farm conservation. Biodiversity International, UK.
Zhao M, Brofeldt S, Li Q, Xu J, Danielsen F, Læssøe SBL. et al. 2016. Can community members identify tropical tree species for REDD+ carbon and biodiversity measurements? PLOS ONE 11 (11): e0152061. DOI: 10.1371/journal. pone.0152061. 